\title{
The Moderating Role of Brand Awareness in The Relationship Between Brand Association and Intention to Pay Zakat in Indonesia Amil Zakat Institution
}

\author{
Muhammad Doddy ${ }^{1}$, Juhary Ali ${ }^{2}$, Cicih Ratnasih ${ }^{3}$ \\ \{muhammad.doddy@sebi.ac.id ${ }^{1}$,juhary.ali@aeu.edu.my ${ }^{2}$, cicihhilali@yahoo.com³ ${ }^{3}$ \\ ${ }^{1}$ Lecturer STEI SEBI and PhD Candidate of Asia e University Malaysia, Depok, Indonesia \\ ${ }^{2}$ Professor of Asia e University Malaysia, Kuala Lumpur ${ }^{2}$, Indonesia \\ ${ }^{3}$ Professor of Universitas Borobudur, Jakarta, Indonesia
}

\begin{abstract}
This research evaluated the impact of brand awareness, brand association, and interaction between brand awareness and brand association on the intention to pay zakat at Dompet Dhuafa Indonesia. Many brand studies on the intention to buy in profitoriented organizations have been conducted. So, this research was performed to see the impact of brand awareness and brand association in non-profit organizations such as amil zakat institution. The study used a quantitative research design using a 100 zakat payer sample to evaluate hypotheses empirically. The results show that brand association has a favorable impact intention to pay zakat. However, brand awareness does not become a moderating variable in the brand association's connection with the intention to pay zakat. The empirical research supplied academics with fruitful consequences by making an essential contribution to the literature on brand and zakat management.
\end{abstract}

Keywords: brand awareness, brand association, intention to pay, brand, zakat mangement.

\section{Introduction}

The potential of zakat funds in Indonesia is relatively high, but the amount that zakat institutions have collected is less than three percent of possible funds. According to BAZNAS, the reality of managing zakat in Indonesia nationally in 2017 is at $2.76 \%$ of the potential of 217 trillion rupiahs ( 15 billion USD) with increasing at an average level of $35.10 \%$ per year from 2002 to 2017 collected by zakat institution. It shows the trend of increasing public awareness of paying zakat that appears to be proportional to an economic standard's rise [1].

Amil Zakat Institution, in Indonesia known as LAZ, is an institution established to collect zakat from muzakki or zakat payer. On the other hand, a task of the Amil Zakat Institution also creates the trust of the muzakki to Amil Zakat Institution for managing their funds appropriately. For this reason, the right marketing strategy needs to be implemented by the amil zakat institution to increase brand awareness and brand association to attract muzakki for paying zakat. Winning minds and market share by increasing brand equity are the goals of general marketing. So, an organization not only has to gain sales (market-share) but also increase brand equity. These objectives will ensure the sustainability of the marketing of the amil zakat institution. Gaining market share is only a short-term goal, while brand equity is a long-term goal [2]. 
Various studies have been conducted on brand awareness and brand association, but more to profit-oriented institutions. There are a few studies on the impact of brand awareness and brand association on non-profit institutions. One of the non-profit institutions is the amil zakat institution. Therefore, in this study, we will examine the extent of the role of the brand equity of the amil zakat institution on the intention and behavior of muzakki.

From the background above, the measurement of the impact of brand awareness and brand association in intention to pay is fascinating if implemented to amil zakat institution. Therefore, the author was then interested in researching about how the strength of the brand association of Dompet Dhuafa as a notable amil zakat institution in intention to pay zakat, moderated by brand awareness.

\section{Literature Review}

The literature review serves the purpose of exchanging results from other research linked to the research at hand. The evaluation of the literature will include a theoretical framework and empirical assessment [3].

\subsection{Theory of planned behavior and intention to pay zakat}

The theory of planned behavior (known as TPB) anchor this paper. Also, payment intention in zakat can be subsumed under the more general notion of "behavioral intention," which involves an intention to buy a product further [4]. The intention is regarded as a prominent antecedent of actual behavior according to the theory of planned behavior [5].

The theory of planned behavior assists this study by offering a theoretical mechanism through which the connection can be developed between the brand association and payment intention. The theory of planned behavior is one of the most essential and well-supported theories of social psychology to predict human behavior [6]. The theory of planned behavior considers that behavioral beliefs, normative beliefs, and control values are affected by individual behavior [7]. Besides, the theory of planned behavior portends that planned behaviors are set by behavioral intentions that are mainly affected by an individual's attitude toward a behavior, the subjective norms encompassing cognitive performance, and the individual's perception of their behavioral control [8].

Fishbein and Ajzen define intention as a subjective probability that a person has to carry out a particular behavior [4]. The intention is the antecedent of visible behavior. Intention can predict different behavioral tendencies accurately. Based on the planned behavior theory, the intention is a function of the three main determinants, first the individual's factor, second the social influence, and third the individual's control [8].

Research on the intention to donate had been carried out in many nations. Similarly, there have also been several studies on Muslims' intention to pay zakat. Also, a recent study clarified an intention to pay zakat on savings with indices of execution, sustainability, location of payment, and income rise [9]. Another research has appended a new indicator, which is payment increases and special payments [10][11].

\subsection{Brand awareness}

Brand awareness is the strength of the customer's brand's existence. This strength is demonstrated by customers' ability to know and remember [12]. Brand awareness is the ability of a brand to appear in the minds of consumers when they assume of a particular category of products and how easily the name can be raised [13]. Brand awareness is a super definition that includes brand knowledge, remembering potential, data, and product thoughts [14]. Jamil 
\& Wong describes brand awareness as a brand consciousness and a brand reminder [15]. Brand awareness is one of the critical variables in generating brand added value and is also seen as one of the key variables influencing the amount of information consumption [16]. The level of brand awareness can be explained as follows: unaware of the brand, brand recognition, brand recall, and top of mind [17].

\subsection{Brand association}

Brand associations are all impressions related to his memory of a brand that appears on someone's mind. If supported by various strong associations, a brand will have a strong competitive market position [18]. The brand association could be used as a general word to represent a connection between two nodes that recommend customer brand association [19]. The brand association would assist customers in finding and dealing with information [20]. Besides, the brand association would provide consumers with a reason for purchase because most brand associations are related to the brand attributes [21]. Brand association, which primarily shapes the brand image, becomes the basis of consumers' decision-making and brand loyalty. The brand association has several types, namely: brand attributes, brand benefits, and brand attitude [17].

\section{Conceptual Model and Hypothesis Development}

A conceptual model to guide the empirical study, as shown in Figure 1, is proposed based on a synthesis of the converging literature related to the research constructs. The conceptual model suggests that brand association is the predictor variable, whereas brand awareness is the moderating variable, and the outcome variable is the intention to pay.

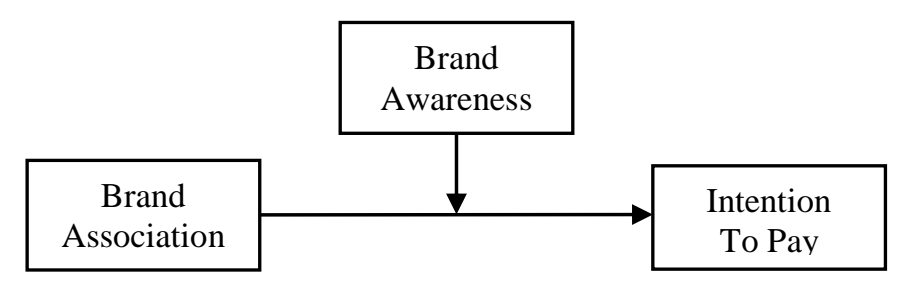

Fig. 1. Conceptual Framework

Brand awareness affects the customer's confidence in purchasing decisions by reducing the level of the perceived risk of a brand that is decided to be purchased [22]. Brand awareness can provide consumer confidence in choosing a brand. In previous studies, brand awareness had a positive effect on purchasing decisions [23] [24]. Therefore it can be identified, that the higher consumer awareness of the brand, it can influence the decision to use or make a purchase of a brand. In the research of amil zakat institutions, studies have shown that the brand awareness of amil zakat institutions has a positive effect on willingness in donation [25]. In various studies, the results obtained indicate that brand association has a significant effect on purchase intentions. Besides, there is also an interaction between brand awareness and brand association [26]. Brand awareness can moderate the relationship between the brand association and purchase intentions. Therefore this study proposes some hypotheses that: 
H1a: Brand awareness has a positive impact on the intention to pay

$\mathrm{H} 1 \mathrm{~b}$ : Brand awareness has a moderation effect on the intention to pay

$\mathrm{H} 2$ : the Brand association has a positive impact on the intention to pay

\section{Research Methodology}

In this research methodology session, it will address how population and samples can be determined, questionnaires designed, and questionnaires distributed. Besides, the data analysis technique will also be considered.

\subsection{Population and Sample}

Samples are described as part of the target population, thoroughly selected to reflect the overall population [27]. The sample is a subgroup of chosen population components to engage in the research [28]. The sampling method utilizes a purposive sampling technique where zakat payers who are not a Dompet Dhuafa member are the target population. In Indonesia, the amount of zakat payers is unknown, and there is no precise information on this issue. The amount of samples we take, therefore, relates to the view that the amount of samples collected is ten times that of variables [29]. Then there are 100 samples we receive. Hair et al. [30] confirm the sample size appropriate for estimating the model is the size between 100 and 200.

\subsection{Questionaire design and data collection}

The questionnaire was circulated to the amil zakat organization online via Google Form and offline via surveyor with a minimum goal of 100 participants who made zakat payments. To filter out whether participants paid zakat, we apply several screening issues. If not, the method of filling will stop automatically. Whether they had valid responses or not, questionnaires were tested again. The questionnaire will not be processed to the next level if there is an indication of a questionnaire that replies carelessly.

The Likert scale is frequently used, which measures attitudes, understanding, perceptions, values, and changes in behavior [31]. To evaluate the information, we use a fivepoint Likert scale ranging from $1=$ strongly disagree to $5=$ strongly agree.

\subsection{Data Analysis Technique}

In data analysis, the model is evaluated based on the outer model and the inner model. The outer model measures the validity and reliability of the construct, while the inner model looks at the value of influence between latent variables.

Validity is a measure that shows that the measured variable is the variable that researchers want to examine [32]. One way to measure validity is to use Confirmatory Factor Analysis (CFA). CFA is used to test theoretical or psychological concepts, or constructs, or variables, which are not directly measurable or observable. The validity value of CFA indicated by the factor loading value is by the number of samples taken. In this study, the number of samples taken was 100 respondents. Then the minimum value of the loading factor is 0.70 [33].

Reliability is the extent to which research findings will be consistent if the study will be carried out again in the future with a different subject sample [34]. This study uses the most popular reliability test, namely Cronbach's alpha coefficient, that is a test of the consistency of 
respondents' answers to all items in size. According to Sekaran, the reliability of less than 0.7 is acceptable [29].

The Average Variance Extracted (AVE) values also were evaluated to evaluate the discriminating validity. Malhotra defines AVE as the variance that is explained by the latent structure in the indices or observed variables. A value of 0.50 or higher is a good measure [33].

To perform calculations through analytical tools, we apply the Partial Least SquareStructural Equation Modeling (PLS-SEM) method in this study. Smart PLS promotes both exploratory and confirmatory study that is robust to deviations for ordinary multivariate distributions and is useful for tiny sample sizes [33].

\section{Results and Discussion}

On these results and discussion sessions, firstly, it will address how respondent profiles and their characteristics. Then, the session also will explain the results of the outer model and inner model with PLS-SEM results.

\subsection{Respondent Profile}

The demographic characteristics of 100 respondents were discussed in the gender, age, education level, the frequency of paying zakat, and the amount of zakat paid. In the sex profile, 55 percent of the respondents are men, and 45 percent of the respondents are men. Whereas in the age profile of donators, the number of respondents is evenly distributed for the age categories 17-25 years, 26-35 years, 36-45 years, and over the age of 45 years. In the education category, zakat payer respondents were dominated by undergraduate graduates by 41 percent.

In terms of frequency of paying zakat, the majority of respondents paying zakat on 1-2 times per year with 71 percent. Also, 43 percent of respondents pay zakat with a value of around 2.1 million IDR -5 million IDR. In the case of where muzakki pay zakat, the majority of respondents pay zakat at the mosque. Then, the amil zakat institution is another alternative place in paying zakat. Based on the type of zakat paid, zakat fitrah is almost entirely paid by muzakki and followed by zakat on income.

\subsection{Outer model and inner model}

The following are the results of the validity and reliability tests of several constructs (see Table 2). Based on the results, all variables have good validity values with factor loading values above 0.70 . The reliability test also meets the required reliability values with Cronbach Alpha above 0.7 and AVE above 0.5 .

Testing the inner model uses multiple regression analysis to see the effect of independent variables on the dependent variable. Multiple regression is used in this paper to study whether the independent variable influences the dependent variable as hypothesized. Multiple regression analysis is done to test the relationship between brand awareness, brand association, and interaction between brand awareness and brand association on the intention to pay zakat. The results are shown in Figure 2: 


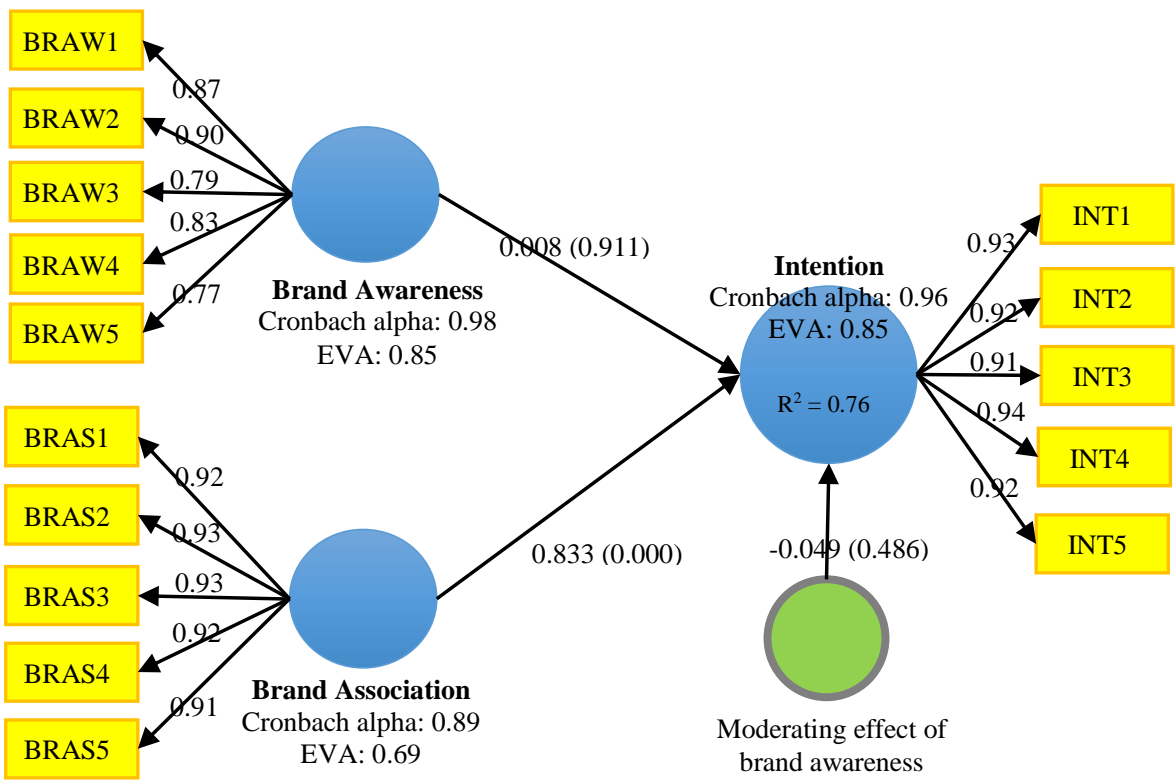

Fig. 2. Path Analysis Results

From the results of multiple regression analysis, it was observed that only one antecedent of intention to pay zakat, namely brand association had significance with P-values below 0.05 with the coefficient value in 0.833 . However, the effect of brand awareness and its interaction with the brand association on the intention to pay zakat is not significant because the P-value exceeds 0.05 . Then, the R-Square value is 0.76 , which means variations from zakat intention to pay can be explained by its independent variables like brand awareness and brand association by 76 percent. With this result, the brand association becomes the primary antecedent of intention to pay zakat. Brand awareness also does not become a moderating variable in the brand association's connection to pay zakat.

\subsection{Implication, Limitation and Future Research}

This study has resulted that in the case of intention to pay zakat, zakat payer intentions are strongly influenced by brand association. The results of this study will have significant implications and are believed to be very useful for the amil zakat institution management. Significant impacts are that amil zakat institutions must build brand association than only building brand awareness. Then, by developing a positive brand association, muzakki is attracted to pay zakat.

During these studies, limitations were noted. First, the research was limited only to the precedent; namely brand awareness and association of brands. A future study could also include factors influencing the intent to reward zakat, such as brand image, brand resonance, and brand trust. Furthermore, the results are based on a sample of 100 respondents that is not larger, which makes it difficult for large populations in Indonesia to generalize the results to other contexts. To get more representative opinions, other scientists could use large sample sizes. This study concentrated on a purely quantitative approach to studies, and other 
scientists could also attempt to use a blended technique or qualitative research approach so that the zakat payer in Indonesia could be viewed in-depth.

\section{Conclusions}

This research aimed to explore the impact of brand awareness, brand association, and interaction between brand awarenss and brand association on intention to pay zakat in Dompet Dhuafa organization as the one of prominent amil zakat institution in Indonesia. Two hypotheses have been postulated in specific. Data were gathered from zakat payer in Jakarta, Indoneisia, to test the suggested hypotheses. The empirical findings provided substantial support for study hypotheses in the connection between brand association and payment intention. Brand awareness does not become a moderating variable in the relationship between brand association with intention to pay zakat. The research shows that in stimulating intention to pay zakat, the brand association is important things.

\section{References}

[1] Badan Amil Zakat Nasional, Statistik Zakat Nasional 2017. Jakarta: Badan Amil Zakat Nasional, 2018.

[2] P. Kotler and K. L. Keller, Marketing Management, 14th ed. New Jersey: Pearson, 2012.

[3] R. Pamacheche, R. Chinomona, and T. Chuchu, "Management ' s Commitment , Education and Ethics on Organisational Entrepreneurship : The Case of South African Non-Profit Organisations," J. Econ. Behav. Stud., vol. 8, no. August, pp. 133-143, 2016.

[4] M. Fishbein and I. Ajzen, Belief, Attitude, Intention, and Behavior. Massachusetts: Addison-Wesley Publishing Company, 1975.

[5] C.-H. S. Lin and C.-F. Chen, "Application of theory of planned behavior on the study of workplace dishonesty," 2010 Int. Conf. Econ. Bus. Manag., vol. 2, pp. 66-69, 2011.

[6] I. Ajzen and T. J. Madden, "Prediction of goal-directed behavior: Attitudes, intentions, and perceived behavioral control," J. Exp. Soc. Psychol., vol. 22, no. 5, pp. 453-474, 1986.

[7] C. Tsai, "Applying the theory of planned behavior to explore the independent travelers behavior," African J. Bus. Manag., vol. 4, no. 2, pp. 221-234, 2010.

[8] I. Ajzen, "The Theory of Planned Behavior," Handb. Theor. Soc. Psychol. London, UK SAGE, vol. 1, no. January 2012, pp. 438-459, 2012.

[9] F. M. N. Azman and Z. Bidin, "Factors influencing zakat compliance behavior on saving," Int. J. Bus. Soc. Res., vol. 05, no. 01, pp. 118-128, 2015.

[10] H. I. Husna, "Intention to Pay Zakah on Employment Income among Manufacturing Employees in Penang," Universiti Utara Malaysia, 2009.

[11] Y. H.- Othman, I. Alwi, M. S. S. Yusuff, and M. S. A. M. Saufi, "The Influence of Attitude, Subjective Norm, and Islamic Religiosity on Compliance Behavior of Income Zakat Among Educators," Int. J. Acad. Res. Bus. Soc. Sci., vol. 7, no. 11, pp. 1110 1116, 2017.

[12] D. A. Aaker, Managing Brand Equity: Capitalizing on the Value of A Brand Name. New York: The Free Press, 1991.

[13] T. A. Shimp and J. C. Andrews, Advertising, Promotion, and Other Aspects of 
Integrated Marketing Communications, 13th ed. Mason: Cengage Learning, 2013.

[14] B. Bilgili and E. Ozkul, "Brand Awareness, Brand Personality, Brand Loyalty and Consumer Satisfaction Relations in Brand Positioning Strategies (a Torku Brand Sample)," J. Glob. Strateg. Manag., vol. 2, no. 9, pp. 89-89, 2015.

[15] B. Jamil and C. H. Wong, "Factors influencing repurchase intention of smartphones," J. Mark. Res., vol. 12, no. 4, pp. 289-94, 2010.

[16] M. E. Malik et al., "Importance of Brand Awareness and Brand Loyalty in Assessing Purchase Intentions of Consumer," Int. J. Bus. Soc. Sci., vol. 4, no. 5, pp. 167-171, 2013.

[17] D. A. Aaker, K. L. Keller, D. A. Aaker, and K. L. Keller, "Consumer Evaluations of Brand," J. Mark., vol. 54, no. 1, pp. 27-41, 1990.

[18] D. A. Aaker, "Measuring Brand Equity Across Products and Markets," Calif. Manage. Rev., vol. 38, no. 3, pp. 102-120, 1996.

[19] H. S. Krishnan, "Characteristics of memory associations: A consumer-based brand equity perspective," Int. J. Res. Mark., vol. 13, no. 4, pp. 389-405, 1996.

[20] J. Boisvert, "Conceptualisation and modelling of the process behind brand association transfer," Int. J. Mark. Res., vol. 53, no. 4, pp. 541-556, 2011.

[21] L. T. Wright, C. Millman, and L. M. Martin, "Research Issues in Building Brand Equity and Global Brands in the PC Market," J. Mark. Manag., vol. 23, no. 1-2, pp. 137-155, 2007.

[22] A. Ekhveh and Z. A. Darvishi, "full-textThe Impact of Brand Awareness on Repurchase Intention of Customers With Trilogy of Emotions Approach (Case Study for Cell Phones)," Appl. Math. Eng. Manag. Technol., vol. 3, no. 4, pp. 25-30, 2015.

[23] V. Ghealita and R. Setyorini, "Pengaruh Brand Awareness Terhadap Keputusan Pembelian AMDK Merek Aqua," Image J. Ris. Manaj., vol. 4, no. 1, pp. 1-9, 2015.

[24] M. Wasil, "Pengaruh brand awareness brand association dan percieved quality The influence of brand awareness brand association and percieved quality," Forum Ekon., vol. 19, no. 2, pp. 137-147, 2017.

[25] D. Mulyono, M. Syamsun, and M. Najib, "The Influence of Social Media in Brand Awareness, Word of Mouth, Intention and Donation Decisionat Rumah Zakat," J. Apl. Manaj., vol. 14, no. 4, pp. 619-628, 2016.

[26] R. Chinomona and E. T. Maziriri, "The influence of brand awareness, brand association and product quality on brand loyalty and repurchase intention: A case of male consumers for cosmetic brands in South Africa," J. Bus. Retail Manag. Res., vol. 12, no. 1, pp. 143-154, 2017.

[27] Sugiyono, Metode Penelitian Kuantitatif Kualitatif dan R\&D. Bandung: CV Alfabeta, 2017.

[28] N. K. Malhotra, D. Nunan, and D. F. Birks, Marketing Research an Applied Approach, 5th ed. Harlow: Pearson.

[29] U. Sekaran, Research Methods for Business. A Skill Building Approach, 4th ed. New York: John Wiley \& Sons, Inc., 2003.

[30] J. F. Hair, W. C. Black, B. J. Babin, and R. E. Anderson, Multivariate Data Analysis, 7th ed., vol. 0. New Jersey: Prentice Hall, 2010.

[31] M. Saunders, P. Lewis, and A. Thornhill, Research Methods for Business Students, 5th ed., vol. 30, no. 1. Harlow: Pearson Education Limited, 2009.

[32] W. Zikmund, B. Babin, J. Carr, and M. Griffin, Business Research Methods, 8th ed. Cengage Learning., 2010.

[33] J. F. Hair, G. T. M. Hult, C. M. Ringle, and M. Sarstedt, A Primer on Partial Least 
Squares Structural Equation Modeling (PLS-SEM). California: SAGE Publications, Inc., 2014.

[34] A. C. Burns, A. Veeck, and R. F. Bush, Marketing Research, 8th ed. Harlow: Pearson Education Limited, 2017. 